\title{
Agricultural Research and the Exchange Problem.
}

Mr. Blanchard is librarian, College of Agriculture, University of Nebraska.

$T^{T}$ wiLl probably be asked-in what way $\mathcal{I}$ are the exchange relations and problems of agricultural libraries different from those of other libraries? Essentially there is little difference except that in agricultural libraries they can assume larger proportions than in libraries specializing in other fields of knowledge. The literature relating to agriculture is enormous and a goodly portion of it is printed in serial publications and bulletins issued by state and national governments all over the world. A great deal is also issued by bodies that are quasi-official in nature. The predominance of official publications in this field is undoubtedly due to the immediate importance of agriculture to the general welfare. Governments find it expedient, for political and social as well as economic reasons, to keep their people well informed of advances in agricultural knowledge. This situation is a mixed blessing for the agricultural library. On the credit side it means many valuable publications are available free of charge-not counting, of course, the processing cost. On the debit side it means that increasing selectivity is necessary to keep our heads above the growing flood of literature and that a well organized exchange program requiring many man hours of work is a vital necessity. Anything that can be done to simplify this

1 Paper presented at a joint meeting of the Agricultural, Engineering and Teacher-Training Sections, A.L.A., Sept. 5. I 949 . task will be of peculiar importance to all libraries specializing in agriculture.

Outside of the U.S.D.A. Library and its branches the majority of agricultural libraries in this country fall into the university and college group. These libraries are, in almost every instance, connected with state agricultural experiment stations and agricultural extension services which issue large quantities of publications each year. Some are general libraries specializing in agriculture and engineering and are a part of the state A. \& M. colleges. Others are concerned almost entirely with agriculture and are connected with colleges of agriculture which form a part of the state universities. As would be expected there are variations in the exchange programs at the different institutions. For illustrative purposes it might be of interest to describe the procedures at the College of Agriculture of the University of Nebraska. The publication of the Nebraska Agricultural Experiment Station literature is under the supervision of the agricultural editor who also assists in the publication of the Nebraska Extension Service material. Maintenance of the mailing lists and the physical task of forwarding the publications of the Experiment Station and the Extension Service are coordinated into one unit. To save handling expense the printed material is not mailed as issued but is forwarded once every three months. Experiment Station bulletins are sent abroad by way of the Smithsonian Institution. Extension Service publications are sent abroad only on special request. The 
exchange of publications is under the jurisdiction of the librarian of the College of Agriculture who must approve all requests for exchange and who initiates such requests. This practice was recommended by the Agricultural Libraries Section and approved by the Association of Land-Grant Colleges and Universities in I94 I with a statement that:

Each librarian of a land-grant college library should cooperate with the director of his Experiment station in establishing a general formula for exchange policies for Station publications. The librarian should have charge of the exchange lists. He should approve each exchange, noting that the library receives publications of equivalent value to those sent. ${ }^{2}$

There is also an exchange section at Love Library on the main campus of the university. The work of both units is, however, very closely integrated. The Love Library unit uses Nebraska agricultural publications, when necessary, to bolster its bargaining position. Arrangements are being made so the College of Agriculture Library can use the general university publications for the same purpose, including on occasion books issued by the University of Nebraska Press. It is hoped eventually to coordinate all of the exchange work of the University of Nebraska into one unit.

There are three aspects of the exchange problem-the exchange of duplicates, domestic exchange and foreign exchange. The exchange of duplicates has been discussed repeatedly at various meetings of the Agricultural Libraries Section. It was felt by many that a system comparable to the Medical Library Association's duplicate exchange arrangement would be useful. The U.S.D.A. Library for several years had a "wants and offers" section in its Agricultural Library Notes which proved helpful in obtaining and disposing of duplicates. In

\footnotetext{
2 U. S. Dent. of Agriculture. Library. Agricul-
} tural Library Notes 17:4, January 1942.
I 929 Claribel Barnett, then U.S.D.A. librarian, suggested that money be contributed by the college and station libraries to pay for the time of an assistant to handle the duplicate exchange work at her library. No permanent arrangement for this suggestion was worked out, however. A general agreement was reached by the Agricultural Libraries Section in $194 \mathrm{I}^{3}$ when it was recommended to the Association of Land-Grant Colleges and Universities that all duplicates of experiment station material be returned, if possible, to their issuing offices. It was felt, and logically enough, that it would be more efficient if issuing offices were the sole source for back copies of their own publications. In practice this arrangement has not always worked too well. Many stations apparently prefer not to be encumbered by large stocks of duplicates or don't have the time to store and dispose of duplicates arriving in odd lots at various times. The I94I meeting also heard the report of the Committee to Investigate the Possibilities of Setting up a Clearing House for Duplicate Public Documents other than State Experiment Station and Extension Division Publications. This committee, although burdened with a long name, made an excellent report in which it was recommended that agricultural libraries join the Association of College and Reference Libraries' duplicate exchange plan rather than start an independent system of their own. We have found at Nebraska that it is practical and satisfactory to list duplicates of agricultural publications on the periodic list which is circulated through the A.C.R.L. membership by the University of Nebraska Libraries. If the A.C.R.L. arrangement continues to work satisfactorily it would not seem necessary to have a separate organization for handling duplicates of agricultural publications. The U.S. Book Exchange is also a means for the disposal and collection

\footnotetext{
${ }^{3}$ U.S.D.A. Library. op. cit.
} 
of duplicates. The Detroit Public Library withdrew from the Duplicate Exchange Union recently, citing the following reasons for its action:

I. The United States Book Exchange will be a much more efficient way of exchanging surplus material between libraries.

2. The time saved becomes a tangible thing when the compilation of exchange lists is eliminated.

3. The time saved by checking several long lists from USBE instead of many short exchange lists will be profitable ${ }^{4}$

The domestic exchange situation presents, as far as I can see, no insuperable difficulties. I would like to make an observation, however-I believe many of us may be paying for domestic publications that we ought to receive free on an exchange basis. If the situation were explored thoroughly, and perhaps some of you have done that already, we would probably find that our experiment station and extension service material is being sent without charge to many associations and organizations who are charging us for their publications. A postcard would no doubt be sufficient in many cases to save us several dollars of subscription money a year. There are some organizations, of course, who operate on such a slender financial margin that it would be impossible for them to supply free copies of their literature. The Association of LandGrant Colleges and Universities has given its blessing to the use of station publications for exchange with "outside" libraries in the following statement:

Libraries not connected with Land-grant colleges, Experiment Stations, or the U.S. Department of Agriculture, but interested in agriculture, shall receive publications of an Experiment Station, if publications of equivalent value are sent on exchange to the library which is associated with the Station. However, no library of an institution or organization primarily interested in agriculture

4 Flaherty, Terese, chief. Book Selection Dept., Detroit Public Library, [Circular letter of May 9, I949]. should be barred from the mailing list because its publications are not of equal value with those of the Station. ${ }^{5}$

The principal difficulties at most institutions are connected with the international exchange situation. Some of these problems are:

I. Exchange relations are haphazard. In many cases exchange with a foreign institution is set up, not because we planned it that way, but because there was a chance inquiry for a certain publication or because the agency abroad wrote and suggested an exchange. An up-to-date list of foreign agricultural institutions which gives the titles of literature available on exchange is badly needed. ${ }^{6} \quad$ As it is now we can only grope in the dark and hope we have full coverage of needed material. Robert B. Downs remarks on this situation in his interesting article "International Exchanges" published in Science: "No list of foreign publications available for exchange is in print, and consequently, arrangements must be negotiated directly between libraries, frequently on a hit-or-miss basis."7

2. The larger research libraries, particularly the U.S.D.A. Library, often receive extra copies of foreign agricultural publications. In most cases there aren't enough copies to send to all the agricultural libraries in this country. The question of how they should be distributed and to which libraries is an important problem.

3. Agricultural libraries receive and process many foreign publications which don't appear to be worthwhile. In some cases the material is simple propaganda or of a popular nature and of little research value. Quite often publications received are in languages so obscure, obscure at least to

5 U.S.D.A. Library. op. cit.

- UNESCO proposes to issue in the near future a manual on the international exchange of publications. An appendix containing a classified list of institutions which are willing to exchange publications will be which are willing to exchange publications will be listing of agricultural institutions will be included.

7 cience n.s. I05:417, 1947. 
Americans, that they are never used. Recent studies made of bibliographies in scientific serial publications published in the United States show the percentage of references cited in languages other than English and German is relatively small. Hermann Fussler, in his exhaustive study "Literature Used by Chemists and Physicists," 8 shows that in $1939,64.5$ per cent of the serial references from a selected list of American journals were published in Great Britain and this country, 25 per cent were published in Germany, 3.0 per cent in France and 7.5 per cent covered the rest of the world. The ratio in 1946 was about the same. James G. Hodgson, in his paper "The Use of Periodicals in a Special Field: Nutrition" 9 found from a study of serial references in the Journal of Nutrition for 1945 and 1946 that "only four nonEnglish titles were recorded among the first 48 in point of use." He points out, however, that this situation could be partly attributed to war conditions which prevented many of the foreign serials from reaching this country. I found in a study of Soil Science that of the 1035 references cited in that journal for I939, 80.3 per cent were issued in the U.S. and the British Commonwealth, I 3 per cent were in German and 2.3 per cent in French. Only 4.4 per cent remained for other languages of the world. The situation was even more lopsided in I 948 when 92.6 per cent of the references were in English, 3.3 per cent in German and I.3 per cent in French, leaving 2.8 per cent for the remaining languages. It must be remembered, of course, that difficult times abroad have affected the amount of foreign agricultural literature published. It is also quite possible that more non-English literature would have been used if it had been more widely available. Even with the material available, however, there is still

${ }^{8}$ Library Quarterly 19:1 28, April 1949.

- Colorado A \& M College Library. Library Bulletin 19. May 1948 . the great barrier of language. Not many of our agricultural research men can read any of the Slavonic, Near Eastern or Far Eastern languages, nor should they be expected to. The number who can read with ease more than one Western European language is certainly small. English language abstracts at the end of articles do help, but the Russians and their satellites seem to be dropping that custom. This paucity of reference to material other than that in the English language would make it appear that our research men aren't true scholars. I found, however, in a study of the Landwirtschaftliche Jahrbücher for 1939 that German scientists show the same tendencies as our own men in that 92 per cent of their references were in German and only 2.9 per cent in English. It would appear, then, that a service that would translate agricultural literature expeditiously, accurately and without too much expense, would be a great boon to research. A committee formed by the Agricultural Libraries Section in 1948, however, found interest in such a project to be negligible. This committee, of which Louise Bercaw, assistant librarian of the U.S.D.A. Library was chairman and of which I was a member, sent questionnaires to all land-grant college libraries asking if they had translation services of their own and if they were satisfactory. They were also asked what translation services they used if there were none available at their own institutions. The questionnaires that were returned indicated the surprising fact that the large majority of colleges had no formal translation services available and that in most cases there appeared to be no particular need for them. With few exceptions a large percentage of the questionnaires indicated that the modern language faculties could handle the small amount of translation work that was necessary. It would appear, then, from this lack of interest in translation services and the 
small percentage of foreign references found in agricultural literature, that we are spending too much time and money in processing some of these publications from abroad. It would certainly be to our advantage if we had available a list which would supply us with authoritative information about exchangeable publications. In this way we would avoid receiving and processing such obscure material and could answer the occasional request for infrequently used items by means of interlibrary loan or by ordering photocopies from the larger research libraries. Many of us are now depending on the U.S.D.A. Library for this service because of its excellent photocopying laboratory and the complete coverage of its $B i b$ liography of Agriculture. It has been suggested, and it might well be feasible, that agricultural libraries receiving publications in out-of-the-way languages send them to the Department of Agriculture Library so that they might be listed in the Bibliography of Agriculture and made available to everybody by a group which can handle the languages concerned. In time we may expect the regional deposit or storage libraries to have on hand literature of this sort. An expressed function of the Midwest Inter-library Corporation is:

To establish and to maintain a Midwest Inter-library Center for the cooperative custody, organization, housing, servicing (and for some materials, ownership) of little used research materials. ${ }^{10}$

What has been done to solve these difficulties and what can we do about them now? There has been in the past, and there still is, a great deal of general interest in the international exchange situation. Governments, learned institutions and librarians have planned and worked for years to have better exchange relations. Activity in this field has increased considerably since the end

10 Frodin, Reuben S. "The Midwest Interlibrary Corporation." A.L.A. Bulletin 43:17r, May 1949. of World War II. The war and its disruptions has made us realize the need for a stronger and more centralized system of exchange which would apply not only to national but to state and private institutions and libraries as well. The creation of UNESCO, with its mandate to encourage international exchanges of all kinds, has also caused greater activity and permits us to hope that sufficient support by librarians throughout the country will eventually bring a solution to this difficult problem. The most extensive discussions in recent years were at the Conference on International, Cultural, Educational, and Scientific Exchanges at Princeton University in 1946. The preliminary memoranda on this conference were written by Edwin E. Williams and Ruth V. Noble and published by A.L.A. in $1947 .^{11}$ This publication summarizes the discussions very admirably and contains excellent historical background material. In spite of these discussions, however, nothing has been done, as far as I know, to solve the international exchange problems of agricultural libraries at a national level. There have been attempts to solve certain parts of the problem. For instance, the U.S.D.A. Library in 1946 sent copies of its foreign mailing list to all directors of agricultural experiment stations, with the hope it would help in putting the stations' mailing lists on a postwar basis. There is also in existence a committee of the Association of Land-Grant Colleges and Universities which is concerned with international exchange relations as they affect land-grant colleges. The chairman, Harold Macy, who is associate director of the Minnesota Agricultural Experiment Station, has written to me that his committee has done some work on compiling a list of for-

11 Williams, Edwin E. and Noble, Ruth. V., Conference on International, Cultural, Educational, and Scientific Exchanges. Princeton University-Nov. 2526, 1946 . Preliminary Memoranda. Recommendations adopted. Summary of discussion. Chicago, American Library Association, 1947. 2 10p. 
eign institutions with which exchange is desirable. ${ }^{12}$ When finished this will probably be similar to Agricultural Research Institutions and Library Centers in Foreign Countries, compiled by Howard Lawton Knight, editor of the Experiment Station Record. The last edition of this list was issued in I 934 by the Office of Experiment Stations. Dr. Macy feels the greatest need is a better arrangement for the distribution of incoming material from abroad and hopes the library people can do something about it. $\mathrm{He}$ believes the present system of distribution to foreign agencies by way of the Smithsonian Institution is satisfactory.

There are several ways in which we can attack these problems. A central exchange agency is an obvious solution. Such an organization could be an agricultural unit forming an integral part of a national center such as the U.S. Book Exchange, or, if that is not feasible, an independent agency handling only agricultural exchanges. In either case I should think such a unit would need to be closely associated with or physically located in the U.S.D.A. Library where extensive mailing lists and contacts with agricultural agencies abroad already exist. The need for national agricultural libraries to take leadership in international exchange relations was noted by Dr. S. von Frauendorfer, formerly librarian of the International Institute of Agriculture, who reported to the 14th International Conference for Documentation in 1938 that "In each country there should be a large central agricultural library which would function as the representative organ for coordinating agricultural documentation within its own country and to which the relations with foreign countries could be entrusted." 13 If this line of reasoning is followed it might also be suggested that the Engineering Societies Library

12 Macy, Harold, [Letter to J. R. Blanchard] June 28, 1949 (Ḿ́).

${ }^{13}$ U.S.D.A. Library. op. cit., 14:48, January 1939. in New York serve as the clearing house for the exchange of engineering literature.

One always asks, if he is practical, how such an agency would be financed. A separate agricultural exchange agency could no doubt depend on some federal funds but would probably need to be supported principally by the individual agricultural libraries or institutions. The success of the Cooperative Acquisition Project and the interest in the Farmington Plan show that cooperative ventures of this sort can succeed. If it is a part of the U.S. Book Exchange, financing would presumably be on a cost per piece basis comparable to the amount charged to American libraries now participating in the U.S.B.E. program. The U.S. Book Exchange, formerly the American Book Center, recently received a grant from the Rockefeller Foundation and is apparenty well on its way to becoming the national exchange bureau. One hundred ninety-four American libraries have subscribed to its program and it has the backing of the Council of National Library Associations, The Library of Congress, UNESCO, the American Council of Learned Societies, the Engineers Joint Council, the American Council on Education and other groups. The U.S.B.E. will accept publications in science and technology for exchange purposes as well as material in other fields of knowledge. Documents, books, pamphlets and most other forms of publications are acceptable except newspapers. At present only institutions in the hard currency countries are charged for this service. The fees are 500 for a bound monograph, $35 \%$ for a periodical issue or unbound monograph and $90 \%$ for a bound periodical. Shipping costs on material received and sent is paid for by the participating libraries. ${ }^{14}$ This agency, if it is successful, may well be the solution to our

14 "United States Book Exchange to Continue under Grant." Librarv Journal 74:184-85, Feb. I, I949. 
exchange problems. It should have, however, a unit that would specialize in the exchange of agricultural publications. American research in agriculture is highly respected abroad. There is a great demand for state agricultural experiment publications which are issued in ever-increasing quantities. If exchange relations for this valuable material were centered in one agency it would mean a bargaining power that would benefit all American libraries. A tremendous saving in time and money would also result. If computed, the time spent on agricultural exchange work in all of the 48 states would surely amount to a respectable total.

An exchange center for agricultural libraries, whether an independent agency or part of a larger group, would, as I visualize it, perform the following tasks:

I. Act as a clearing house for exchange relations between agricultural institutions in this country and abroad. The need for a clearing house of this sort is illustrated by a difficulty experienced by the College of Agriculture Library in Nebraska. One of our principal interests there is soil science. Because of this one of our research men who reads Russian is particularly interested in the Russian magazine Pedology (Pochvovedenie). We have not, however, received this journal since 1947. Inquiries have been sent to Russia on two occasions asking about Pedology but there has been no reply in either case. We send the Nebraska Agricultural Experiment Station material to 22 addresses in the Soviet Union and have been receiving currently several publications from that country-but not the publication in which we are most interested. A central exchange agency, with its contacts abroad and greater inflence, could possibly straighten this matter out for us. Unfortunately the present international situation makes even this possibility rather doubtful.

2. Maintain a list of foreign agricultural institutions containing descriptive notes about their publications which are available for exchange.

3. Distribute duplicates of foreign agricultural publications received by the U.S.D.A. Library and other large research libraries. A depository library for each region, designated by the interested libraries themselves, would be a possible solution. A distribution based on subject interest might also be feasible. This was done by the Cooperative Acquisition Project. Ralph Shaw and Luther Evans both spoke of this problem at the conference at Princeton. Dr. Evans stated that "many documents are received in more than one copy, but the Library of Congress has no pattern for their distribution and would like to see one developed."15 Mr. Shaw spoke of the need to help the states in their document acquisition and exchange programs and remarked that the U.S.D.A. Library occasionally receives multiple copies of foreign journals with a request that it help to establish exchanges. He observed that there should be a group representing state and private institutions to determine how such items should be distributed. ${ }^{16}$

If it is felt an exchange agency is not feasible, an alternative would be to appoint committees of agricultural librarians who could give aid and advice to organizations that are in a position to do something about these questions. For instance we can encourage and offer our help to Dr. Macy's committee in the hope that its projected list of foreign agricultural institutions can be completed in the near future. We might also ask the Library of the Food and Agriculture Organization or the U.S.D.A. Library to carry on in the footsteps of the International Institute of Agriculture and give us a new edition of the International

(Continued on page 53)

15 Williams. $o p$. cit., p. 77.

16 Ibid., p. 82 . 
anxious to cooperate with their customers, the libraries. The head of a technical services department is in a good position to smooth the path toward better relations in this sphere. If he knows his work, he is conversant with the problems of the order division, the catalogers, the serial records staff and the people preparing material for binding. With this knowledge, he is better prepared to present the over-all problems of the library to the dealer and to work out means of cooperation with him. On the other hand there are the faculty and the student body. In his relations with them the technical services specialist is able to bring about better understanding by developing ways and means of getting the ma- terials they need into the library more. quickly, and of cataloging and classifying them more satisfactorily. The resulting satisfaction will pay large dividends.

These are only some of the numerous devices which can be utilized in a technical services department to streamline and improve operations. More can be found, and in the discovery and application of these the specialist in this field will find a constant challenge and a rewarding satisfaction. This is not a static field, but a constantly changing one, which offers great possibilities to the adventurous. Life is never dull, and the person entering this field can expect to enjoy his work while helping to improve library technique.

\section{Agricultural Research and the Exchange Problem}

\section{(Continued from page 46)}

Directory of Agricultural Libraries and of Libraries Specialized in Subjects Related to Agriculture (Rome, The Institute, 1939. 3 I Ip.) Revisions of other lists issued by the International Institute of Agriculture, such as the International Directory of Animal Husbandry Institutions (Rome, 1933. 322p.), the International Directory of $\mathrm{Ag}$ ricultural Engineering Institutions (Rome, 1939. I 52p.), the International Directory of Dairying Institutions (Rome, I934. 450p.), the International Directory of $\mathrm{Ag}$ ricultural Experimental Institutions in $\mathrm{Hot}$ Countries (Rome, 1934. 563p.), and In- stitutions Agricoles dan les Pays Tempérés (Rome, 1933. 306p.), would also be of great value. We could certainly attack, through regional committees, the question of which libraries were to be designated as depositories for duplicates of foreign agricultural material received by the larger research libraries. In any case I propose that we attempt to do something concrete about the foreign exchange situation. If enough interest is aroused I see no reason .why a decision in favor of decisive action cannot be reached at the national meeting of the A.L.A. in July 1950. 